\title{
Aquatic macrophytes can be used for wastewater polishing but not for purification in constructed wetlands
}

\author{
Yingying Tang ${ }^{1, *}$, Sarah F. Harpenslager ${ }^{1, a,{ }^{*}, \text { Monique M. L. van Kempen }}{ }^{1}$, Evi J. H. Verbaarschot ${ }^{2}$, \\ Laury M. J. M. Loeffen ${ }^{1}$, Jan G. M. Roelofs ${ }^{2}$, Alfons J. P. Smolders ${ }^{1,2}$, and Leon P. M. Lamers ${ }^{1}$ \\ ${ }^{1}$ Department of Aquatic Ecology and Environmental Biology, Institute for Water and Wetland Research, \\ Radboud University, P.O. Box 9010, 6500 GL Nijmegen, the Netherlands \\ ${ }^{2}$ B-Ware Research Centre, Radboud University, P.O. Box 6558, 6503 GB Nijmegen, the Netherlands \\ ${ }^{\mathrm{a}}$ current address: School of Biological and Chemical Sciences, Queen Mary University, London, UK \\ ${ }^{*}$ These authors contributed equally to this work.
}

Correspondence to: Yingying Tang (nicoletangyingying@126.com)

Received: 8 March 2016 - Discussion started: 2 May 2016

Revised: 5 January 2017 - Accepted: 16 January 2017 - Published: 20 February 2017

\begin{abstract}
The sequestration of nutrients from surface waters by aquatic macrophytes and sediments provides an important service to both natural and constructed wetlands. While emergent species take up nutrients from the sediment, submerged and floating macrophytes filter nutrients directly from the surface water, which may be more efficient in constructed wetlands. It remains unclear, however, whether their efficiency is sufficient for wastewater purification and how plant species and nutrient loading affects nutrient distribution over plants, water and sediment. We therefore determined nutrient removal efficiencies of different vegetation (Azolla filiculoides, Ceratophyllum demersum and Myriophyllum spicatum) and sediment types (clay, peaty clay and peat) at three nutrient input rates, in a full factorial, outdoor mesocosm experiment. At low loading $\left(0.43 \mathrm{mg} \mathrm{P} \mathrm{m}^{-2} \mathrm{~d}^{-1}\right)$, plant uptake was the main pathway $(100 \%)$ for phosphorus $(\mathrm{P})$ removal, while sediments showed a net $\mathrm{P}$ release. A. filiculoides and $M$. spicatum showed the highest biomass production and could be harvested regularly for nutrient recycling, whereas $C$. demersum was outcompeted by spontaneously developing macrophytes and algae. Higher nutrient loading only stimulated A. filiculoides growth. At higher rates $\left(\geq 21.4 \mathrm{mg} \mathrm{P} \mathrm{m}^{-2} \mathrm{~d}^{-1}\right), 50-90 \%$ of added $\mathrm{P}$ ended up in sediments, with peat sediments becoming more easily saturated. For nitrogen (N), 45-90\% was either taken up by the sediment or lost to the atmosphere at loadings $\geq 62 \mathrm{mg} \mathrm{N} \mathrm{m}^{-2} \mathrm{~d}^{-1}$. This shows that aquatic macrophytes can indeed function as an efficient nutrient filter but only for
\end{abstract}

low loading rates (polishing) and not for high rates (purification). The outcome of this controlled study not only contributes to our understanding of nutrient dynamics in constructed wetlands but also shows the differential effects of wetland sediment types and plant species. Furthermore, the acquired knowledge may benefit the application of macrophyte harvesting to remove and recycle nutrients from both constructed wetlands and nutrient-loaded natural wetlands.

\section{Introduction}

Excess loading of phosphorus $(\mathrm{P})$ and nitrogen $(\mathrm{N})$ from domestic, agricultural and industrial wastewaters is the main cause of eutrophication of aquatic ecosystems, damaging their ecological quality and functioning (Kronvang et al., 2005; Kantawanichkul et al., 2009). Surface water eutrophication can lead to algal and cyanobacterial blooms, die-off of indigenous vegetation, and a serious decrease in biodiversity (Pretty et al., 2003; Conley et al., 2009). In recent decades, wetlands have been constructed to mitigate eutrophication of watercourses, lakes and seas by reducing the nutrient loads in discharge water of wastewater treatment plants, farmlands, households or industries (Brix and Arias, 2005; Mitsch et al., 2005).

Constructed wetland systems (CWSs) use macrophytes or a combination of macrophytes and sediment to remove nutrients from the water (Brix, 1994; Vymazal, 2007). These 
systems are either used as stand-alone water purification systems (Vrhovšek et al., 1996; Jing et al., 2001) or as a polishing method of pretreated wastewater (Kaseva, 2004; Greenway, 2005). The most commonly used macrophyte species are emergent genera such as Typha, Phragmites, Scirpus, Phalaris and Iris (Vymazal, 2011). Advantages of CWS include the utilization of natural processes, low cost and energy requirements, and easy operation and maintenance (Brix, 1999; Konnerup et al., 2009). As a result of low maintenance, however, these systems easily become saturated with $\mathrm{P}$ and other nutrients, which decreases their nutrient-binding capacity. As a result, they only work efficiently for a limited amount of time (Drizo et al., 2002). Furthermore, at higher latitudes seasonality is an important factor for these systems because additional energy will be needed during cold seasons (see, e.g., the use of warmed greenhouse facilities) to remove nutrients by macrophyte growth year-round (Wittgren and Mæhlum, 1997).

Although much research has focused on the optimal design of CWS with respect to the most efficient macrophyte species (Lin et al., 2002; Scholz and Xu, 2002), only few studies have investigated the possibility of using floating or submerged aquatic macrophytes in treatment systems. Although these studies showed that submerged or floating macrophytes can be used to remove nutrients from wastewater due to their high growth rates, they did not elaborate on nutrient removal efficiencies under different nutrient loadings (Vymazal, 2007; Gao et al., 2009). While helophytes mainly take up nutrients from the sediment, floating and submerged aquatic macrophytes, such as Azolla spp. or Myriophyllum spp., can also take up nutrients from the water layer (Best and Mantai, 1978; Van Kempen et al., 2012). By regularly harvesting these plants, nutrients may be removed from the system. The aquatic biomass can then be used in various bio-based applications, for instance, as a bio-fertilizer or as fodder for livestock (Hauck, 1978; Biswas and Sarkar, 2013).

There is a suite of mechanisms involved in the processes of nutrient removal and recovery in natural and constructed wetlands, including sediment adsorption; phosphate $\left(\mathrm{PO}_{4}^{3-}\right)$ adsorption by aluminium $(\mathrm{Al})$, iron $(\mathrm{Fe})$ or calcium $(\mathrm{Ca})$; precipitation; plant absorption; volatilization, and microbial processes such as iron oxidation, nitrification, DNRA (dissimilatory nitrate reduction to ammonium) and anammox (anaerobic ammonium oxidation) (Van Loosdrecht and Jetten, 1998; Van Dongen et al., 2001; Kadlec and Wallace, 2008; Wu et al., 2014). Rates and removal efficiencies by these mechanisms are generally affected by factors such as nutrient loading, plant species and sediment type (Gale et al., 1994; Tanner, 1996; Jampeetong et al., 2012). So far, most studies have focused on the effects of only one or two of these factors on nutrient retention in wetlands, whereas little information is available on interactions among plant species, sediment type and nutrient loading. Only by including all interactions, however, can the nutrient sequestration efficiency of wetland plants and sediments under different loads be assessed.
Here, we studied the effects of plant species, nutrient loading and sediment type on nutrient uptake rates of aquatic macrophytes and nutrient retention rates of sediments. Using a full-factorial outdoor mesocosm experiment, we studied the nutrient uptake rates of three different aquatic macrophytes with contrasting growth forms (Azolla filiculoides, Ceratophyllum demersum and Myriophyllum spicatum), growing on peat, peaty clay or clay sediments. Three different, environmentally relevant, nutrient loadings of $\mathrm{P}(0.43,21.4$ and $\left.85.7 \mathrm{mg} \mathrm{P} \mathrm{m}^{-2} \mathrm{~d}^{-1}\right)$ and $\mathrm{N}\left(1.3,62\right.$ and $\left.249 \mathrm{mg} \mathrm{N} \mathrm{m}^{-2} \mathrm{~d}^{-1}\right)$ were applied to the mesocosms, representing pretreated (low nutrient loading) and eutrophic and hypertrophic wastewater input (medium and high nutrient loading) (Lamers et al., 2002). By studying the resulting distribution of $P$ and $N$ among the different sediment, macrophyte and water compartments, we aimed to determine the nutrient removal efficiency of floating and submerged aquatic macrophytes with regard to wastewater at low (polishing) or high (purification) loading rates and the interacting role of sediment type.

\section{Materials and methods}

\subsection{Experimental setup}

Twenty-seven mesocosms $(185 \mathrm{~cm} \varnothing, 90 \mathrm{~cm}$ depth) were sunk into the ground outside the greenhouse facility at Radboud University (Nijmegen, the Netherlands). All mesocosms were filled with $20 \mathrm{~cm}(135 \mathrm{~L})$ of carefully homogenized clay (originating from Lalleweer, $53^{\circ} 16^{\prime} \mathrm{N}, 6^{\circ} 59^{\prime} \mathrm{E}$; $n=9$ ), peaty clay (originating from De Deelen, $53^{\circ} 01^{\prime} \mathrm{N}$, $5^{\circ} 55^{\prime} \mathrm{E} ; n=9$ ) or peat (originating from Ilperveld, $52^{\circ} 27^{\prime} \mathrm{N}$, $4^{\circ} 56^{\prime} \mathrm{E} ; n=9$ ), after which they received a layer of $50 \mathrm{~cm}$ of Nijmegen tap water $\left(\mathrm{NH}_{4}^{+}<0.03 \mathrm{mg} \mathrm{L}^{-1} ; \mathrm{NO}_{3}^{-}\right.$: $16.40 \mathrm{mg} \mathrm{L}^{-1} ; \mathrm{PO}_{4}^{3-}<0.03 \mathrm{mg} \mathrm{L}^{-1} ; \mathrm{pH}: 7.7$; total inorganic carbon (TIC): $30 \mathrm{mg} \mathrm{CL}^{-1}$ ). Sediment characteristics are displayed in Table 1, expressed per unit volume to enable comparison among sediment types with respect to nutrient exchange and plant nutrient availability. In all mesocosms, crossed transparent carbon fiber plates were used to create four fully isolated quarters. We did not include non-vegetated treatments because (1) our focus was on complete ecosystems in constructed and natural wetlands, i.e., including sediment and vegetation; (2) bare sediments always show spontaneous vegetation development if light and nutrient conditions suffice (see Sect. 2.2); (3) continuous plant removal would lead to significant sediment disturbance; and (4) dark conditions would affect sediment biogeochemistry. Mesocosms were randomly assigned to low (L), medium (M) or high $(\mathrm{H})$ nutrient-loading treatment $(n=3$ for all). To create these, treatment solutions were added three times a week to the surface water to enable loading rates of $0.43,21.4$ and $85.7 \mathrm{mg} \mathrm{Pm}^{-2} \mathrm{~d}^{-1}$ (added as $\mathrm{NaH}_{2} \mathrm{PO}_{4} \cdot \mathrm{H}_{2} \mathrm{O}$ and atmospheric deposition of $0.1 \mathrm{~kg} \mathrm{Pha}^{-1} \mathrm{yr}^{-1}$ ) (Furnas, 2003) and 1.3, 62 and $249 \mathrm{mg} \mathrm{N} \mathrm{m}^{-2} \mathrm{~d}^{-1}$ (added as $\mathrm{NH}_{4} \mathrm{NO}_{3}$ and 


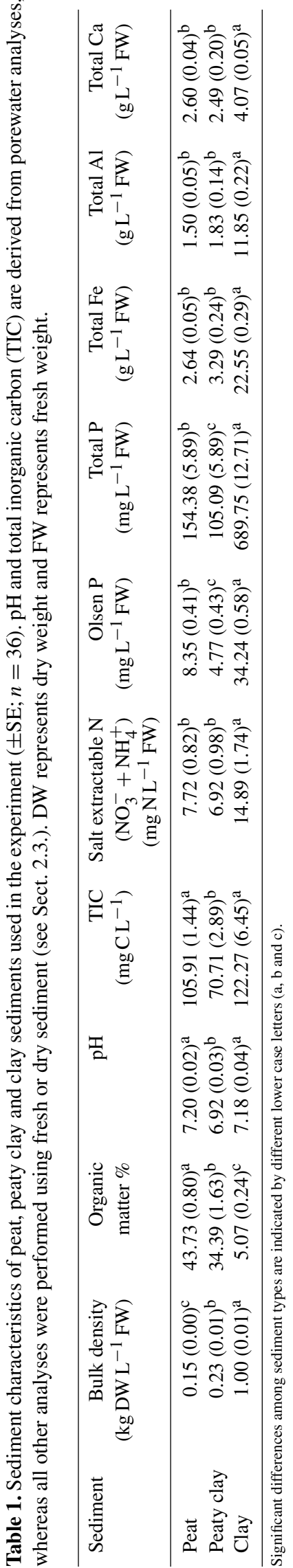

atmospheric $\mathrm{N}$ deposition of $35 \mathrm{~kg} \mathrm{Nha}^{-1} \mathrm{yr}^{-1}$ in this part of the Netherlands) (RIVM, 2016). In the "Results" and the "Discussion" sections, treatments will be referred to as 0.43 (low), 21.4 (medium) and 85.7 (high) $\mathrm{mg} \mathrm{P} \mathrm{m}^{-2} \mathrm{~d}^{-1}$, according to their respective $\mathrm{P}$ loading.

\subsection{Plant measurements}

In July 2013, environmentally relevant densities (based on personal field observations) (De Lyon and Roelofs, 1986) of Ceratophyllum demersum $\left(5.03 \pm 0.24 \mathrm{~g} \mathrm{DW} \mathrm{m}^{-2}\right.$ (DW is dry weight); rigid hornwort, submerged macrophyte), Chara hispida $\left(8.66 \pm 0.69 \mathrm{~g} \mathrm{DW} \mathrm{m}^{-2}\right.$; bristly stonewort, submerged macroalga) and Myriophyllum spicatum $\left(5.31 \pm 0.60 \mathrm{~g} \mathrm{DW} \mathrm{m}^{-2}\right.$; Eurasian water milfoil, submerged macrophyte) were planted randomly in each of three quarters of every mesocosm to establish themselves. In April 2014, patches of Azolla filiculoides $\left(28.39 \pm 0.88 \mathrm{~g} \mathrm{DW} \mathrm{m}^{-2}\right.$; water fern, floating macrophyte) were added to the water layer of the remaining quarter. Apart from these four introduced species, other species colonized the quarters, including Zanichellia spp. and floating algae. As C. hispida was completely outcompeted by spontaneously developing vegetation, the quarters with this species were excluded from the rest of this study. During the experimental period, $20 \%$ of the total plant biomass (for rooted macrophytes aboveground biomass only) was harvested when vegetation reached $100 \%$ cover to avoid space limitation. During the final harvest, biomass of all present species was harvested separately and dried $\left(48 \mathrm{~h}\right.$ at $\left.60^{\circ} \mathrm{C}\right)$, after which it was weighed, ground and homogenized.

\subsection{Chemical analyses}

Surface water samples were collected every week between May and October 2014, whereas pore water samples were collected anaerobically every month using ceramic soil moisture samplers (SMS Rhizon, Eijkelkamp, Giesbeek, the Netherlands). The $\mathrm{pH}$ of water samples was measured between 12:00 and 14:00 (UTC + 2) using a combined $\mathrm{Ag} / \mathrm{AgCl}$ electrode (Orion, Thermo Fisher Scientific, Waltham, MA, USA) with a TIM840 pH meter (Radiometer Analytical, Lyon, France). TIC of water samples was measured using an infrared gas analyzer (IRGA; ABB Analytical, Frankfurt, Germany). Concentrations of $\mathrm{PO}_{4}^{3-}$, $\mathrm{NO}_{3}^{-}$and $\mathrm{NH}_{4}^{+}$in the surface water and pore water were measured colorimetrically on an Auto-Analyzer III system (Bran and Luebbe, Norderstedt, Germany) by using ammonium molybdate (Henriksen, 1965), hydrazine sulfate (Kamphake et al., 1967) and salicylate (Grasshoff and Johannsen, 1972), respectively. Concentrations of total $P$ were measured by inductively coupled plasma optical emission spectrometry (ICP-OES; IRIS Intrepid II, Thermo Fisher Scientific, Franklin, MA, USA). 
Sediment samples were collected at the end of the experiment, and subsequently volume-weighted and dried for $48 \mathrm{~h}$ at $60{ }^{\circ} \mathrm{C}$ to determine bulk density. Dry sediment samples were heated for $4 \mathrm{~h}$ at $550^{\circ} \mathrm{C}$ and reweighed to determine organic matter content. Furthermore, $200 \mathrm{mg}$ of dry sediment was digested in a microwave oven (MLS-1200 Mega, Milestone Inc., Sorisole, Italy) with $4 \mathrm{~mL} 65 \% \mathrm{HNO}_{3}$ and $1 \mathrm{~mL} 30 \% \mathrm{H}_{2} \mathrm{O}_{2}$, after which digestates were analyzed and concentrations of total $\mathrm{Al}, \mathrm{Fe}, \mathrm{Ca}$ and $\mathrm{P}$ in sediments were determined by ICP-OES (see above). Plant-available $\mathrm{P}$ was determined by extraction according to Olsen et al. (1954), whereas an $\mathrm{NaCl}$ extraction was performed to determine exchangeable $\mathrm{N}$ ions $\left(\mathrm{NO}_{3}^{-}+\mathrm{NH}_{4}^{+}\right)$as described in Tomassen et al. (2004). Total $\mathrm{P}$ concentrations in plants were determined by digestion of $200 \mathrm{mg}$ of dry plant material and analyzed as described above. Furthermore, $3 \mathrm{mg}$ of dry plant material was combusted to determine $\mathrm{C}$ and $\mathrm{N}$ content using an elemental analyzer (Carlo Erba NA 1500, Thermo Fisher Scientific, Waltham, MA, USA).

\subsection{Budget calculations}

For both $\mathrm{N}$ and $\mathrm{P}$, nutrient budgets were calculated to determine the distribution among biomass, sediment and other components. Cumulative biomass production and the nutrient content of submerged or floating macrophytes (target species and others) were used to calculate plant uptake rates of $\mathrm{N}$ and $\mathrm{P}$. Furthermore, nutrient changes in surface water and pore water were calculated from changes in $\mathrm{N}\left(\mathrm{NO}_{3}^{-}\right.$and $\mathrm{NH}_{4}^{+}$) and total $\mathrm{P}$ concentrations (end minus start). After subtracting the $\mathrm{N}$ and $\mathrm{P}$ uptake of plants and water components from the external loading, we assume that the remainder is either stored in the sediment or, in the case of $\mathrm{N}$, lost through coupled nitrification-denitrification (Wetzel, 2001).

\subsection{Statistical analyses}

All analyses were performed using the software program $\mathrm{R}$ (version 3.2.1; R Development Core Team, 2015). The effects were considered significant if $P<0.05$. In order to meet the assumption that residuals fit a normal distribution and homogeneity of variance, we transformed sediment characteristics, $\mathrm{N}\left(\mathrm{NO}_{3}^{-}\right.$and $\left.\mathrm{NH}_{4}^{+}\right)$and $\mathrm{P}$ concentrations in surface water, biomass production rates, $\mathrm{N}: \mathrm{P}$ ratios in macrophytes, $\mathrm{N}$ and $\mathrm{P}$ budgets, and $\mathrm{N}$ and $\mathrm{P}$ sequestration rates (response variables) by $\log$ (response variable) or $\log$ (response variable +1$)$ in the case of the lowest value of a variable being below 1. Linear mixed models were used to test the main effects and the interactions of treatments on sediment characteristics, biomass production rates, the ratios between $\mathrm{N}$ and $\mathrm{P}$, and nutrient budgets with the mesocosm number as a random effect by using $R$ package nlme. The main effects (including nutrient loading, sediment type, plant species and time) and interactions of treatments on $\mathrm{N}\left(\mathrm{NO}_{3}^{-}\right.$and $\left.\mathrm{NH}_{4}^{+}\right)$ and $\mathrm{P}$ concentrations in surface water were also tested by lin-

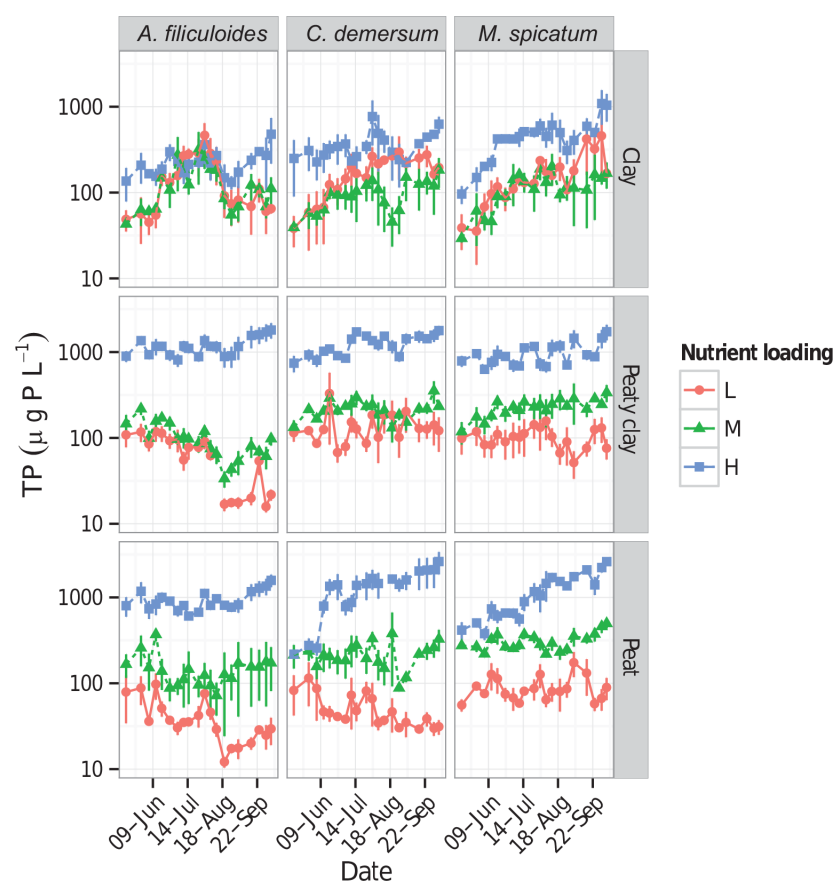

Figure 1. Surface water total $P$ (TP) concentrations subjected to different nutrient loadings (L: $0.43 \mathrm{mg} \mathrm{P} \mathrm{m}^{-2} \mathrm{~d}^{-1}$; M: $21.4 \mathrm{mg} \mathrm{P} \mathrm{m}^{-2} \mathrm{~d}^{-1} ; \mathrm{H}$ : $85.7 \mathrm{mg} \mathrm{P} \mathrm{m}^{-2} \mathrm{~d}^{-1}$ ) in mesocosms with different plant species (vertical panels) on clay, peaty clay or peat sediments (horizontal panels) during the experiment. Average TP concentrations are given with standard error of the mean (SEM). Note the $\log _{10}$ scale for the $y$ axis.

ear mixed models. Tukey tests were used to find differences between treatments by using $\mathrm{R}$ package multcomp. We analyzed the influence of nutrient loadings on $\mathrm{P}$ and $\mathrm{N}$ sequestration (uptake plus adsorption to plants) rates using linear and logistic regression models with the summary function. All graphs were plotted using R package ggplot2.

\section{Results}

\subsection{Surface water and pore water quality}

Over time, surface water $\mathrm{P}$ and $\mathrm{N}\left(\mathrm{NH}_{4}^{+}+\mathrm{NO}_{3}^{-}\right)$concentrations increased (Figs. 1 and 2; $X^{2}=3.44, P<0.05$ and $X^{2}=23.63, P<0.001$ for $\mathrm{P}$ and $\mathrm{N}$, respectively), especially towards the end of the growing season. There were significant interactions between time and plant species $\left(X^{2}=\right.$ $10.18, P<0.01)$ for surface water $\mathrm{P}$ and between time and nutrient loadings $\left(X^{2}=8.92, P<0.05\right)$ for surface water $\mathrm{N}$. When macrophytes were growing on peat or peaty clay sediments, $\mathrm{P}$ concentrations in the surface water increased with increasing external $\mathrm{P}$ loading $\left(X^{2}=99.80, P<0.001\right.$ and $X^{2}=59.40, P<0.001$ for peat and peaty clay sediments, respectively). 
Table 2. Plant tissue ratios between $\mathrm{N}$ and $\mathrm{P}$ for different macrophytes subjected to different nutrient loadings (0.43, 21.4 and $85.7 \mathrm{mg} \mathrm{P} \mathrm{m}^{-2} \mathrm{~d}^{-1}$ ) at the end of the experiment. Average $\mathrm{N}: \mathrm{P}$ ratios of target species are given with standard error.

\begin{tabular}{llrrr}
\hline Species & Soil type & \multicolumn{3}{c}{$\mathrm{N}: \mathrm{P}(\mathrm{g}: \mathrm{g})$} \\
\cline { 3 - 5 } & & 0.43 & 21.4 & 85.7 \\
\hline \multirow{2}{*}{ A. filiculoides } & Clay & $15.70( \pm 0.47)^{\mathrm{a}}$ & $19.36( \pm 1.86)^{\mathrm{a}}$ & $8.07( \pm 0.58)^{\mathrm{b}}$ \\
& Peaty clay & $22.22( \pm 1.65)^{\mathrm{a}}$ & $10.88( \pm 0.29)^{\mathrm{b}}$ & $5.07( \pm 0.14)^{\mathrm{c}}$ \\
& Peat & $18.94( \pm 0.10)^{\mathrm{a}}$ & $10.92( \pm 0.88)^{\mathrm{b}}$ & $5.80( \pm 0.34)^{\mathrm{c}}$ \\
\hline C. demersum & Clay & $4.03( \pm 0.61)$ & $4.14( \pm 0.50)$ & $\mathrm{NA}$ \\
& Peaty clay & $4.21( \pm 0.44)$ & $4.08( \pm 0.72)$ & $3.63( \pm 0.38)$ \\
& Peat & $7.66( \pm 1.94)^{\mathrm{a}}$ & $4.26( \pm 0.31)^{\mathrm{a}, \mathrm{b}}$ & $3.40( \pm 0.42)^{\mathrm{b}}$ \\
\hline M. spicatum & Clay & $4.71( \pm 0.63)$ & $4.42( \pm 0.24)$ & $4.16( \pm 0.87)$ \\
& Peaty clay & $6.01( \pm 0.81)^{\mathrm{a}}$ & $4.63( \pm 0.25)^{\mathrm{a}, \mathrm{b}}$ & $3.80( \pm 0.34)^{\mathrm{b}}$ \\
& Peat & $4.58( \pm 0.53)$ & $4.36( \pm 0.17)$ & $3.77( \pm 0.35)$ \\
\hline
\end{tabular}

Significant differences among different nutrient loadings are indicted by different lower case letters $(\mathrm{a}, \mathrm{b}$ and c); there were no significant differences among sediment types. Note that NA means that there were no replicates for this treatment.

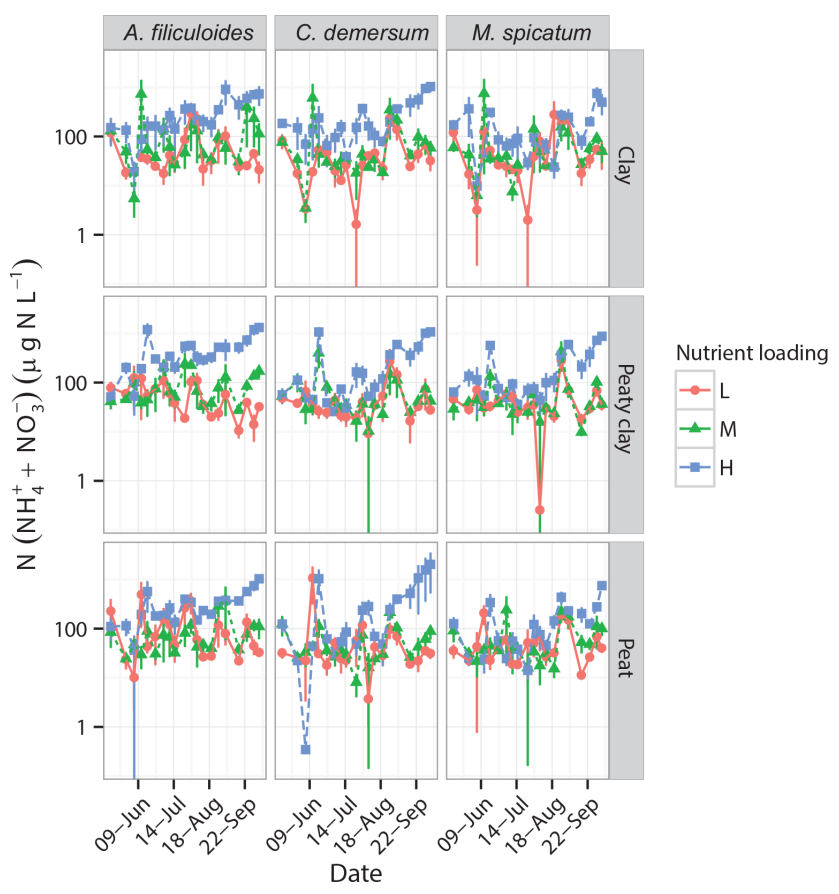

Figure 2. Surface water $\mathrm{N}\left(\mathrm{NH}_{4}^{+}+\mathrm{NO}_{3}^{-}\right)$concentrations subjected to different nutrient loadings ( $\mathrm{L}: 0.43 \mathrm{mg} \mathrm{Pm}^{-2} \mathrm{~d}^{-1} ; \mathrm{M}$ : $21.4 \mathrm{mg} \mathrm{P} \mathrm{m}^{-2} \mathrm{~d}^{-1} ; \mathrm{H}: 85.7 \mathrm{mg} \mathrm{P} \mathrm{m}^{-2} \mathrm{~d}^{-1}$ ) in mesocosms with different plant species (vertical panels) on clay, peaty clay or peat sediments (horizontal panels) during the experiment. Average $\mathrm{N}$ $\left(\mathrm{NH}_{4}^{+}+\mathrm{NO}_{3}^{-}\right)$concentrations are given with standard error of the mean (SEM). Note the $\log _{10}$ scale for the $y$ axis.
Porewater nutrient concentrations depended on sediment type. Peat sediments had the highest $\mathrm{P}$ concentrations in the pore water, whereas the lowest were found in clay sediments $\left(X^{2}=20.20, P<0.001 ; 4.65 \pm 0.15\right.$ and $0.71 \pm 0.05 \mathrm{mg} \mathrm{L}^{-1}$ for peat and clay, respectively), even though total $\mathrm{P}$ and Olsen $\mathrm{P}$ concentrations were much higher in clay than in the other two sediments (Table 1). In addition, mesocosms filled with peat sediments had higher $\mathrm{N}$ concentrations in the pore water than those with peaty clay and clay $\left(X^{2}=7.13, P<0.05\right.$; data not shown). Surface water and porewater together never contained more than $12 \%$ of total $\mathrm{P}$ and $\mathrm{N}$ added to the system at $\mathrm{P}$ loadings $\geq 21.4 \mathrm{mg} \mathrm{P} \mathrm{m}^{-2} \mathrm{~d}^{-1}$ (Figs. 4 and 5).

\subsection{Macrophyte productivity and nutrient ratio}

Due to their high biomass production rates, A. filiculoides and $M$. spicatum could be harvested weekly and biweekly, respectively. A. filiculoides had the highest biomass production rates of all three macrophyte species $\left(X^{2}=55.45\right.$, $P<0.001$ ), whereas $C$. demersum grew best on peaty clay sediments $\left(X^{2}=10.67, P<0.01\right)$ but almost disappeared when growing on clay and peat sediments due to competition with algae and other non-target species (Fig. 3). Biomass production rates of $A$. filiculoides were significantly higher at high nutrient loading than at low nutrient loading ( $\left.X^{2}=11.39, P<0.01\right)$, whereas no effect of nutrient loading was found for the other macrophytes. In quarters with $C$. demersum, there was a higher production rate of nontarget species than in quarters with A. filiculoides and $M$. spicatum $\left(X^{2}=6.28, P<0.05\right)$. A. filiculoides showed high $\mathrm{N}: \mathrm{P}$ ratios $\left(>11 \mathrm{~g} \mathrm{~g}^{-1}\right)$ when grown at $\leq 21.4 \mathrm{mg} \mathrm{P} \mathrm{m}^{-2} \mathrm{~d}^{-1}$ $(P<0.001)$, whereas all other species generally showed $\mathrm{N}: \mathrm{P}$ ratios ranging from 4 to $8 \mathrm{gg}^{-1}$, without an effect of sediment type (Table 2). 

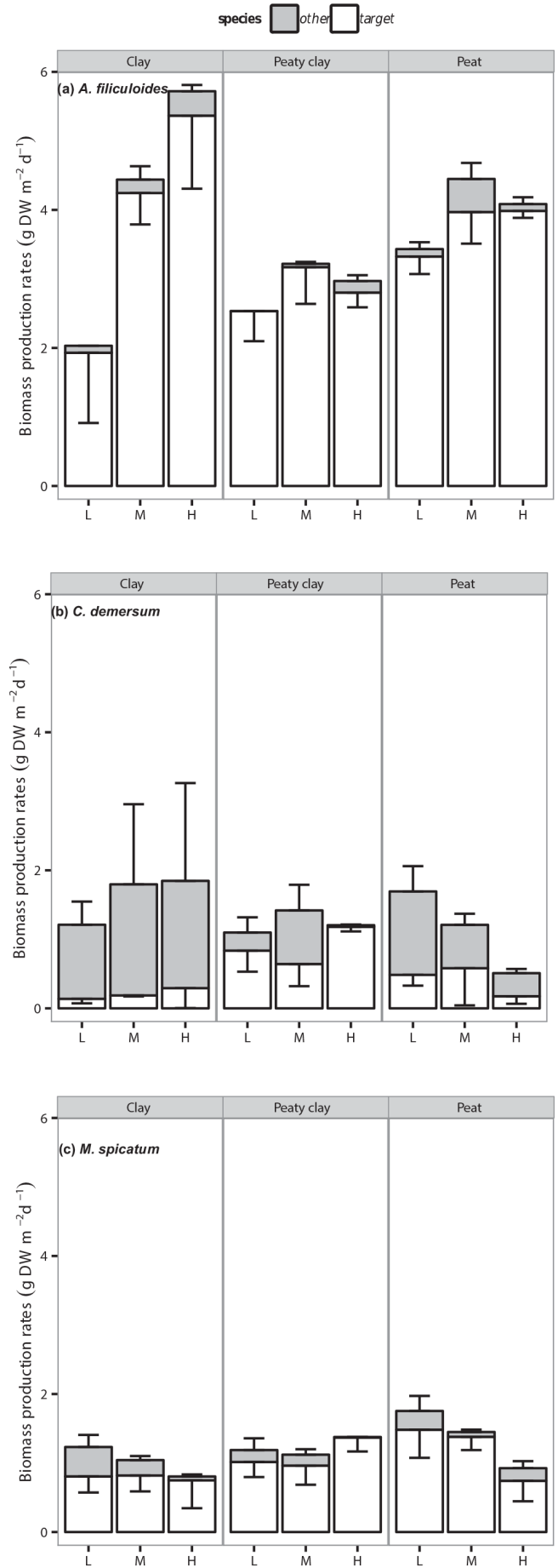

Figure 3. Biomass production rates (in $\mathrm{g} \mathrm{DW} \mathrm{m}^{-2} \mathrm{~d}^{-1}$ ) of $A$. filiculoides (a), C. demersum (b), M. spicatum (c) and other, nontarget plants (e.g., floating algae, Zanichellia spp. and other plants) grown on different sediment types and subjected to different nutrient loadings (L: $0.43 \mathrm{mg} \mathrm{P} \mathrm{m}^{-2} \mathrm{~d}^{-1} ; \mathrm{M}: 21.4 \mathrm{mg} \mathrm{P} \mathrm{m}^{-2} \mathrm{~d}^{-1} ; \mathrm{H}$ : $\left.85.7 \mathrm{mg} \mathrm{P} \mathrm{m}^{-2} \mathrm{~d}^{-1}\right)$. Average biomass production rates of target species $(-$ SEM) and other plants $(+$ SEM) are given.

\subsection{Plant nutrient uptake}

A. filiculoides and M. spicatum accumulated much more $\mathrm{P}$ than $C$. demersum $\left(X^{2}=23.66, P<0.001\right.$; Fig. 4$)$. At a $\mathrm{P}$ loading of $0.43 \mathrm{mg} \mathrm{m}^{-2} \mathrm{~d}^{-1}$, around $100 \%$ of added $\mathrm{P}$ and $\mathrm{N}$ were accumulated by the targeted macrophytes (Figs. 4 and 5). For the quarters with A. filiculoides or M. spicatum, around $20-40$ and $10-20 \%$ of the $\mathrm{P}$ added was taken up by target species at $\mathrm{P}$ loadings of 21.4 and $85.7 \mathrm{mg} \mathrm{m}^{-2} \mathrm{~d}^{-1}$, respectively, regardless of sediment types. $C$. demersum never took up more than $20 \%$ of the P added at these loadings. Still, at a loading of $85.7 \mathrm{mg} \mathrm{P} \mathrm{m}^{-2} \mathrm{~d}^{-1}$, removal rates by macrophytes were significantly higher than at $0.43 \mathrm{mg} \mathrm{P} \mathrm{m}^{-2} \mathrm{~d}^{-1}$ $\left(X^{2}=7.22, P<0.05\right.$; Fig. 4$)$. The average $\mathrm{P}$ sequestration rates by $A$. filiculoides and $M$. spicatum were 3 to $9 \mathrm{mg} \mathrm{m}^{-2} \mathrm{~d}^{-1}$ at $\mathrm{P}$ loadings $\leq 21.4 \mathrm{mg} \mathrm{m}^{-2} \mathrm{~d}^{-1}$. At a high $\mathrm{P}$ loading of $85.7 \mathrm{mg} \mathrm{m}^{-2} \mathrm{~d}^{-1}$, the average $\mathrm{P}$ removal rates by A. filiculoides and M. spicatum were 16 to 20 and 6 to $14 \mathrm{mg} \mathrm{m}^{-2} \mathrm{~d}^{-1}$, respectively. In quarters with C. demersum, more $\mathrm{P}$ was taken up by other, spontaneously developing species than in quarters with A. filiculoides and M. spicatum $\left(X^{2}=6.89, P<0.05\right)$. A. filiculoides and M. spicatum sequestrated much more $\mathrm{N}$ than $C$. demersum and the final biomass of $A$. filiculoides had the highest $\mathrm{N}$ content (including $\mathrm{N}_{2}$ fixed) among all macrophyte species $\left(X^{2}=10.28\right.$, $P<0.01$; Fig. 5). At high $\mathrm{N}$ loadings, less than $21 \%$ of added $\mathrm{N}$ was removed by the targeted macrophytes. In addition, $C$. demersum had higher $\mathrm{P}$ and $\mathrm{N}$ uptake rates in mesocosms with peaty clay compared to mesocosms with clay $\left(X^{2}=10.50, P<0.01 ; X^{2}=10.43, P<0.01\right)$.

For $C$. demersum, nutrient sequestration rates increased linearly with increased nutrient loading, while for $M$. spicatum there was a logistic response to external nutrient loading (Fig. 6). A. filiculoides showed linearly increasing P sequestration rates upon increased $\mathrm{P}$ loading and a logistic response to external $\mathrm{N}$ loading.

\subsection{Mobilization and adsorption of nutrients by the sediment}

At a $\mathrm{P}$ loading of $0.43 \mathrm{mg} \mathrm{m}^{-2} \mathrm{~d}^{-1}$, sediments were sources of $\mathrm{P}$, whereas sediments became $\mathrm{P}$ sinks at $\mathrm{P}$ loading $\geq 21.4 \mathrm{mg} \mathrm{m}^{-2} \mathrm{~d}^{-1}$ (Fig. 4). On average, 50 to $80 \%$ and 70 to $90 \%$ of $\mathrm{P}$ added accumulated in sediments at medium and high nutrient loadings, respectively (Fig. 4). In quarters with $C$. demersum, more $\mathrm{P}$ accumulated in the sediment than in quarters with $A$. filiculoides $\left(X^{2}=11.25, P<0.01\right)$. At medium and high $\mathrm{N}$ loads, 45 to $90 \%$ and 80 to $90 \%$, respectively, was either taken up by the sediment or lost to the atmosphere through coupled nitrification-denitrification (Wetzel, 2001). 

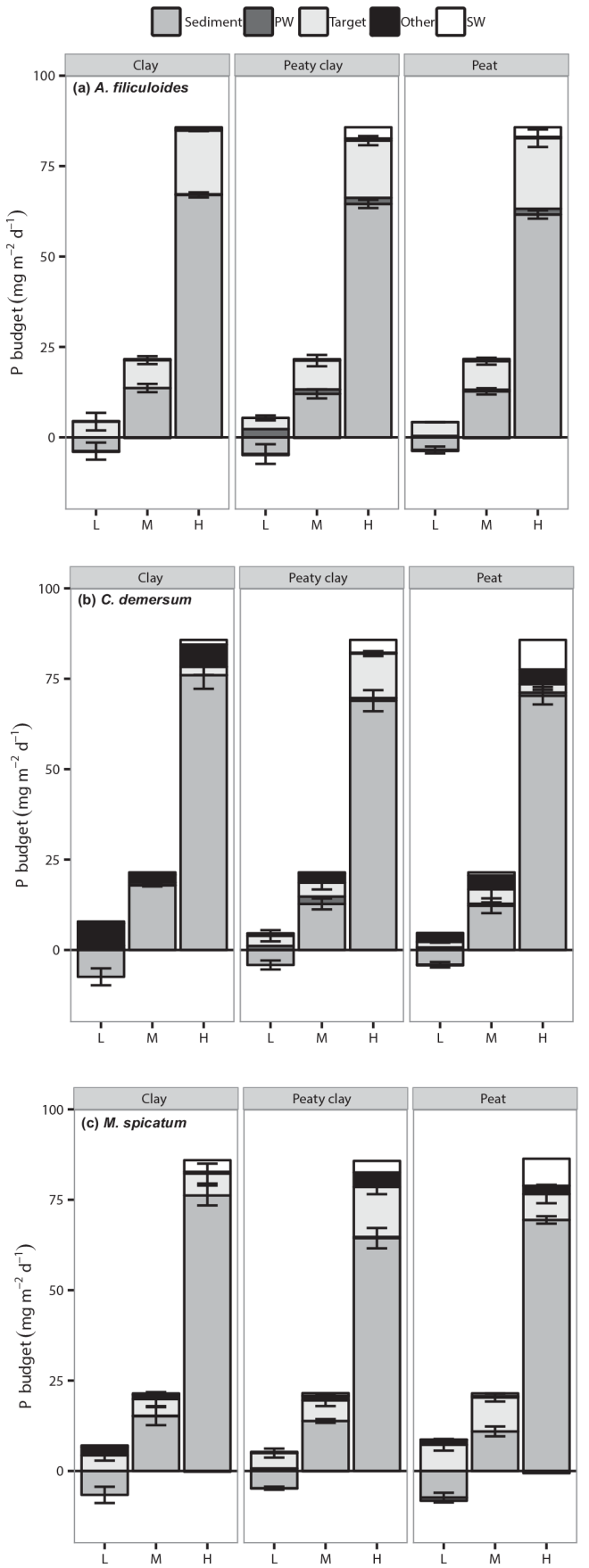

Figure 4. $P$ budgets of sediment, surface water, pore water, target species and other plants subjected to different nutrient loadings ( $\mathrm{L}$ : $0.43 \mathrm{mg} \mathrm{P} \mathrm{m}^{-2} \mathrm{~d}^{-1}$; M: $21.4 \mathrm{mg} \mathrm{P} \mathrm{m}^{-2} \mathrm{~d}^{-1} ; \mathrm{H}$ : $85.7 \mathrm{mg} \mathrm{P} \mathrm{m}^{-2} \mathrm{~d}^{-1}$ ) for (a) A. filiculoides, (b) C. demersum, and (c) M. spicatum. Standard errors are given only for sediment and target species. PW: pore water; SW: surface water. Positive values represent $\mathrm{P}$ accumulation in relative parts; negative values represent $\mathrm{P}$ release from respective compartments.
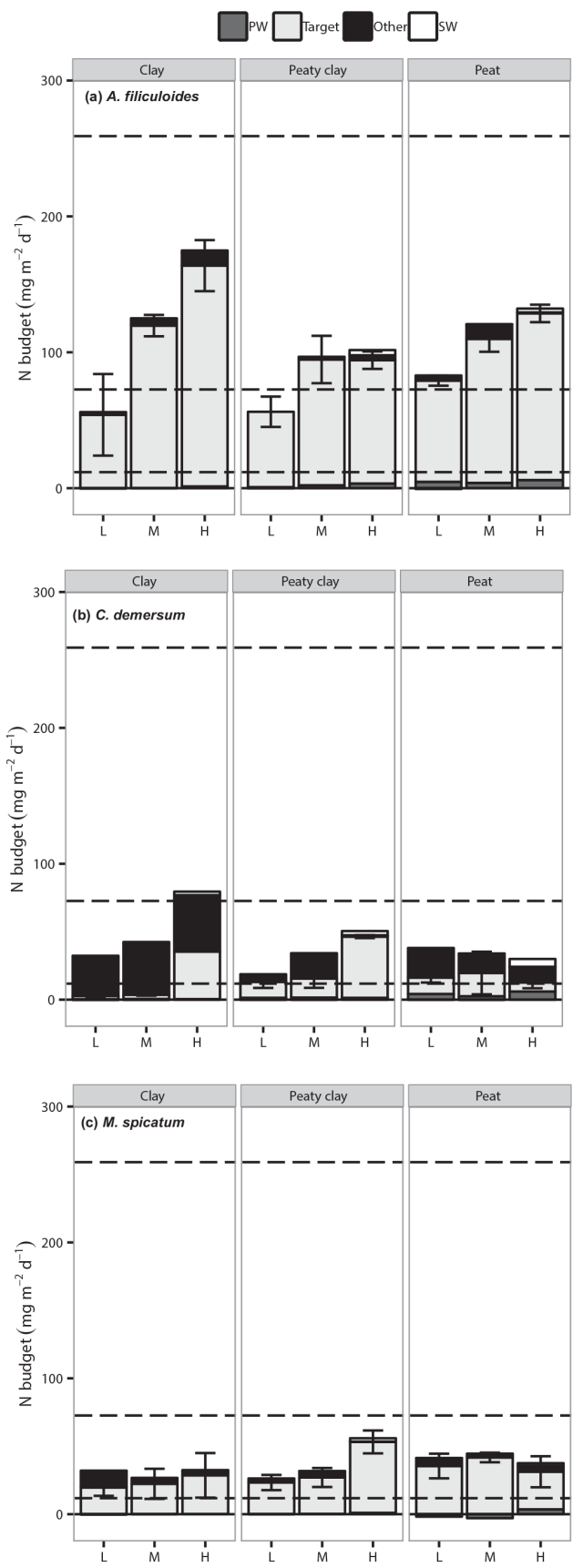

Figure 5. $\mathrm{N}$ distribution in surface water, pore water, target species and other plants subjected to different nutrient loadings (L: $0.43 \mathrm{mg} \mathrm{P} \mathrm{m}^{-2} \mathrm{~d}^{-1} ; \quad \mathrm{M}: 21.4 \mathrm{mg} \mathrm{P} \mathrm{m}^{-2} \mathrm{~d}^{-1} ; \mathrm{H}$ : $85.7 \mathrm{mg} \mathrm{P} \mathrm{m}^{-2} \mathrm{~d}^{-1}$ ) from (a) A. filiculoides, (b) C. demersum and (c) M. spicatum macrophyte systems. Standard errors are given only for target plants. PW: pore water; SW: surface water. Positive values represent $\mathrm{N}$ accumulation in relative parts; negative values represent $\mathrm{N}$ release from respective compartments. The lowest, medium and highest dashed lines represent external $\mathrm{N}$ input at low, medium and high $\mathrm{N}$ loadings (including actual atmospheric $\mathrm{N}$ deposition), respectively. 

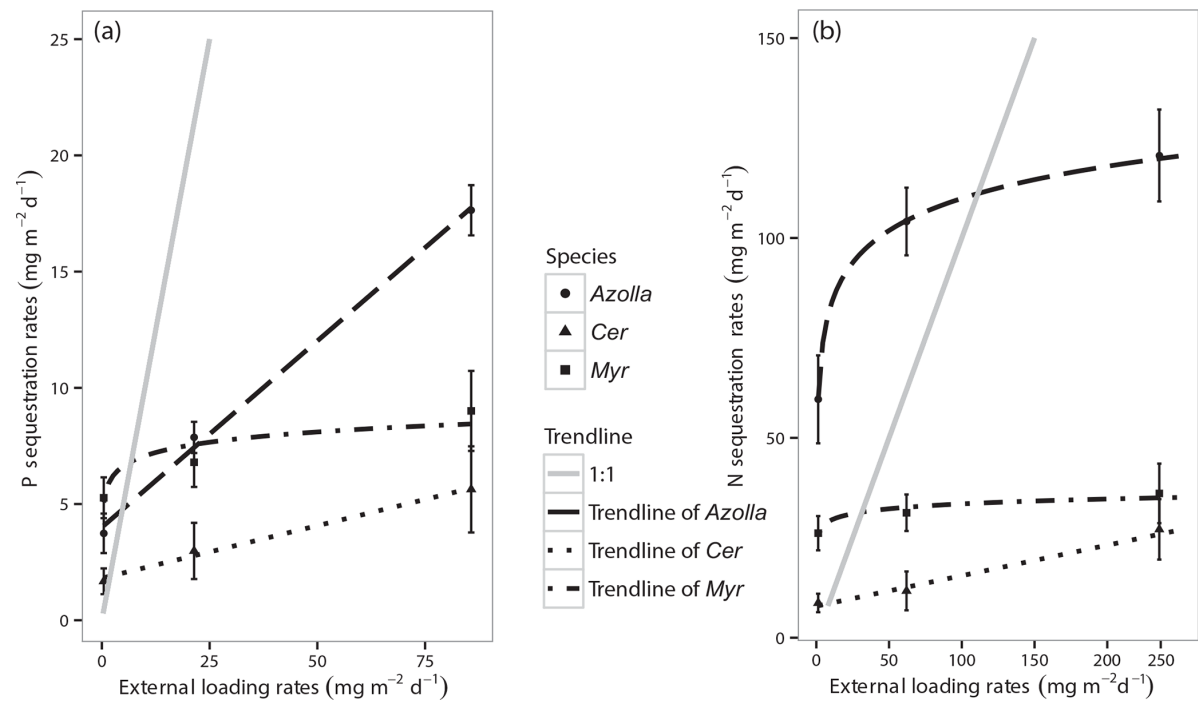

Figure 6. The correlations between external loading and nutrient sequestration rates of $\mathrm{P}$ (a) and $\mathrm{N}$ (b) by three different aquatic plant species. Standard errors and 1: 1 line are given. Note that for A. filiculoides $\mathrm{N}_{2}$ fixation is included in the sequestration rates, overestimating the effects of loading.

\section{Discussion}

In our mesocosm experiment, we show that at low nutrient input $\left(\leq 0.43 \mathrm{mg} \mathrm{P} \mathrm{m}^{-2} \mathrm{~d}^{-1}\right), 100 \%$ of external loading could be removed through macrophyte uptake, whereas with loadings $\geq 21.4 \mathrm{mg} \mathrm{P} \mathrm{m}^{-2} \mathrm{~d}^{-1}, 50$ to $90 \%$ of added $\mathrm{P}$ ended up in sediments. Differences exist, however, between binding abilities of sediments, with clay sediments being able to immobilize $\mathrm{P}$ better than peaty clay or peat sediments. Apart from $\mathrm{P}$, macrophytes were able to remove no more than 65 and $21 \%$ of added $N$ at loadings of 62 and $249 \mathrm{mg} \mathrm{m}^{-2} \mathrm{~d}^{-1}$, respectively, while the remaining $\mathrm{N}$ was either stored in the sediment or lost to the atmosphere through coupled nitrification-denitrification. Furthermore, this study also shows that $\mathrm{N}$ removal efficiency of macrophytes strongly depends on the plant species involved.

\subsection{Growth and nutrient uptake of macrophyte species in constructed wetlands}

With average biomass production rates of 3.4 and $1.0 \mathrm{~g} \mathrm{DW} \mathrm{m}^{-2} \mathrm{~d}^{-1}$, respectively, A. filiculoides and $M$. spicatum showed the highest growth rates, regardless of sediment type and nutrient loading, and therefore have the best potential for being used to remove nutrients in constructed wetlands. Due to their high growth rates, these species could be harvested biweekly or even weekly. C. demersum, on the other hand, appeared to be less suitable, since this species was easily outcompeted for light by other species, such as floating algae and Zanichellia spp. $\mathrm{P}$ was removed most efficiently by $A$. filiculoides, followed by $M$. spicatum and $C$. demersum. Although a high $\mathrm{P}$ load $\left(85.7 \mathrm{mg} \mathrm{m}^{-2} \mathrm{~d}^{-1}\right)$ resulted in increased uptake rates of 6 to 14 and even 16 to
$20 \mathrm{mg} \mathrm{P} \mathrm{m}^{-2} \mathrm{~d}^{-1}$ for M. spicatum and A. filiculoides, respectively, these rates were not sufficient to efficiently filter all added $\mathrm{P}$ from the system.

Different response types between species to external nutrient loading most likely resulted from differences in main nutrient sources and nutrient limitation (Fig. 6). For rooted $M$. spicatum, plants mainly rely on sediment uptake (Best and Mantai, 1978; Barko and Smart, 1980; Carignan and Kalff, 1980), whereas for non-rooted A. filiculoides and $C$. demersum, water is the main nutrient source (Denny, 1987; Mjelde and Faafeng, 1997). Our results indicate that at a low nutrient loading, M. spicatum and A. filiculoides performed equally well for $\mathrm{P}$ removal, whereas at loads $\geq 22 \mathrm{mg} \mathrm{P} \mathrm{m}^{-2} \mathrm{~d}^{-1}, A$. filiculoides removes $\mathrm{P}$ more efficiently (Fig. 6a). In addition, the effective thresholds for $\mathrm{P}$ purification (100\% removal) of $C$. demersum, A. filiculoides and $M$. spicatum are 1.9, 4.8 and $6.8 \mathrm{mg} \mathrm{P} \mathrm{m}^{-2} \mathrm{~d}^{-1}$, respectively (Fig. 6a). Threshold values for complete $\mathrm{N}$ removal are 8.6 and $31.4 \mathrm{mg} \mathrm{N} \mathrm{m}^{-2} \mathrm{~d}^{-1}$ for $C$. demersum and $M$. spicatum, respectively (Fig. 6b). A. filiculoides, on the other hand, hardly ever becomes $\mathrm{N}$ limited due to its symbiosis with a diazotrophic microbial community (Handley and Raven, 1992). Under low external P loadings, A. filiculoides therefore displayed very high $\mathrm{N}: \mathrm{P}$ ratios, indicating $\mathrm{P}$ limitation at $\mathrm{P}$ loadings $\leq 21.4 \mathrm{mg} \mathrm{P} \mathrm{m}^{-2} \mathrm{~d}^{-1} . C$. demersum, on the other hand, having no access to sediment or atmospheric $\mathrm{N}$, probably showed $\mathrm{N}$ limitation in these systems, as indicated by their low $\mathrm{N}: \mathrm{P}$ ratios. For all species, $\mathrm{N}: \mathrm{P}$ ratios decreased with increasing $\mathrm{P}$ load. 


\subsection{Using aquatic macrophytes for polishing pretreated wastewater}

Due to regular harvesting of A. filiculoides and M. spicatum, $\mathrm{P}$ and $\mathrm{N}$ were removed at rates of around 3 to $9 \mathrm{mg} \mathrm{P} \mathrm{m}^{-2} \mathrm{~d}^{-1}$ and $31 \mathrm{mg} \mathrm{N} \mathrm{m}^{-2} \mathrm{~d}^{-1}$ at loadings of $0.43 \mathrm{mg} \mathrm{P} \mathrm{m}^{-2} \mathrm{~d}^{-1}$ and $1.3 \mathrm{mg} \mathrm{N} \mathrm{m}^{-2} \mathrm{~d}^{-1}$. These results are comparable to those found by Van Kempen (2013), who found uptake rates of $3.7 \mathrm{mg} \mathrm{P} \mathrm{m}^{-2} \mathrm{~d}^{-1}\left(13.4 \mathrm{~kg} \mathrm{ha}^{-1} \mathrm{yr}^{-1}\right)$ and $13.7 \mathrm{mg} \mathrm{N} \mathrm{m}^{-2} \mathrm{~d}^{-1} \quad\left(50 \mathrm{~kg} \mathrm{ha}^{-1} \mathrm{yr}^{-1}\right)$ in summer and $4.8 \mathrm{mg} \mathrm{m}^{-2} \mathrm{~d}^{-1} \quad\left(17.5 \mathrm{~kg} \mathrm{ha}^{-1} \mathrm{yr}^{-1}\right)$ and $69.3 \mathrm{mg} \mathrm{N} \mathrm{m}^{-2} \mathrm{~d}^{-1}\left(253 \mathrm{~kg} \mathrm{ha}^{-1} \mathrm{yr}^{-1}\right)$ in the early fall for A. filiculoides grown in $\mathrm{N}$-free water with $2.38 \mathrm{mg} \mathrm{L}^{-1} \mathrm{PO}_{4}$. For M. spicatum, our results are in the same range as those reported by Smith and Adams (1986) and the N uptake rates of $0.05-1.26 \mathrm{~g} \mathrm{~N} \mathrm{~m}^{-2} \mathrm{~d}^{-1}$ by Myriophyllum aquaticum reported by Nuttall (1985). As low $\mathrm{O}_{2}$ concentrations, induced by the coverage of floating macrophytes or dense growth of submerged macrophytes, can mobilize $\mathrm{P}$ from the sediment, A. filiculoides and M. spicatum did not only take up all $\mathrm{P}$ being discharged into the system by both their roots and shoots but additionally took up mobilized P (Wetzel, 2001).

Since the uptake of nutrients by aquatic macrophytes depends on their biomass production and thus on macrophyte photosynthesis, these systems would only function optimally during the growing season (Wetzel, 2001). Under low external loading, sediments will take up most of the $\mathrm{P}$ during winter. Since submerged plants have $\mathrm{N}$ and $\mathrm{P}$ accumulation rates that are higher than the low nutrient loading, they heavily rely on the uptake of nutrients from the sediment. Thus, the nutrients stored in the sediment in winter can be mobilized and taken up by macrophytes in summer, creating an efficient and sustainable constructed wetland for water polishing in temperate climates. Furthermore, predicted climate change will lead to higher temperatures and thus longer growing seasons in temperate regions, indicating that these systems may be operational longer and longer every year.

\subsection{Using aquatic macrophytes for wastewater purification}

When $\mathrm{P}$ loading in the treatment water increases, uptake rates of A. filiculoides double or even triple to rates of 7.87 or $17.64 \mathrm{mg} \mathrm{P} \mathrm{m}^{-2} \mathrm{~d}^{-1}$. The highest value is lower than the results of Reddy and DeBusk (1985), who reported P uptake rates of $43 \pm 15 \mathrm{mg} \mathrm{m}^{-2} \mathrm{~d}^{-1}$ by A. filiculoides grown in an $\mathrm{N}$-free, $3 \mathrm{mg} \mathrm{L}^{-1} \mathrm{P}$ medium which, however, had much higher $\mathrm{PO}_{4}^{3-}$ concentrations in the surface water than our high nutrient-loading treatment. $\mathrm{P}$ uptake rates of A. filiculoides in this study are similar to, or even lower than, the results of Brix (1994), who reported P uptake rates of 8 $41 \mathrm{mg} \mathrm{P} \mathrm{m}^{-2} \mathrm{~d}^{-1}$ by emergent macrophytes. The main advantage of using floating macrophytes instead of emergent macrophytes is, however, that they can be harvested multi- ple times a year and that they take up nutrients from both the water layer and the sediment. Although plants could not take up all $\mathrm{P}$ at medium or high external $\mathrm{P}$ loadings, overall surface water quality remained around or below $0.37 \mathrm{mg} \mathrm{L}^{-1}$ when clay sediments were used for the construction of the wetland. At the end of the growing season, however, plant uptake decreased and $\mathrm{P}$ availability in surface waters above peaty clay and peat sediments increased strongly to concentrations around 1.86 and $2.23 \mathrm{mg} \mathrm{PL}^{-1}$, respectively, indicating not only inactivity of aquatic macrophytes but probably also P saturation of sediments. Due to the 7-8 times higher $\mathrm{Fe}$ and $\mathrm{Al}$ contents (22.6 vs. $2.6-3.3 \mathrm{~g} \mathrm{~L}^{-1} \mathrm{FW}$ (fresh weight) and 11.9 vs. $1.5-1.8 \mathrm{~g} \mathrm{~L}^{-1} \mathrm{FW}$ for $\mathrm{Fe}$ and $\mathrm{Al}$, respectively) of clay sediments, $\mathrm{P}$ was most probably immobilized more efficiently by clay (Reddy and DeLaune, 2008), which resulted in lower P concentrations in surface water above clay sediments in our study.

More than $98 \%$ of added $\mathrm{N}$ was removed from the surface water during the run of the experiment. As nutrient loading increased, the amount of added $\mathrm{N}$ that was removed by plant uptake decreased. Harvested biomass of target plants contained $31 \mathrm{mg} \mathrm{N} \mathrm{m}^{-2} \mathrm{~d}^{-1}$ for $M$. spicatum, whereas in the quarters with $C$. demersum, non-target macrophytes or algae sequestrated most $\mathrm{N}$. Although it can be estimated that $\mathrm{N}_{2}$ fixation rates by Azolla grown in an $\mathrm{N}$-free medium were in the range of $1.4-2.7 \mathrm{~kg} \mathrm{Nha}^{-1} \mathrm{~d}^{-1}$ (Reddy and DeBusk, 1985), in our study we added $\mathrm{N}$ to the surface water which may affect $\mathrm{N}_{2}$ fixation. Therefore, it was difficult to calculate $\mathrm{N}$ removal rates for $A$. filiculoides, as the unknown $\mathrm{N}_{2}$ fixation rates lead to an overestimation of $\mathrm{N}$ uptake rates by $A$. filiculoides. $\mathrm{N}$ that was not taken up by plants but was still removed from the water layer most likely ended up in the sediment or was released to the atmosphere by coupled nitrification-denitrification (Wetzel, 2001). On average, inorganic $\mathrm{N}\left(\mathrm{NH}_{4}^{+}+\mathrm{NO}_{3}^{-}\right)$concentrations in the surface water were below $0.11 \mathrm{mg} \mathrm{L}^{-1}$ with external loadings $\leq 62 \mathrm{mg} \mathrm{N} \mathrm{m}^{-2} \mathrm{~d}^{-1}$ and around $0.28 \mathrm{mg} \mathrm{L}^{-1}$ when receiving $249 \mathrm{mg} \mathrm{N} \mathrm{m}^{-2} \mathrm{~d}^{-1}$. At the end of the growing season, dissolved $\mathrm{N}$ concentrations increased under high nutrient loading, similar to $\mathrm{P}$ concentrations. This increase may result from a combination of reduced plant uptake, nutrient leaching from senescing plants and reduced denitrification rates as a result of lower temperatures. Due to the different available pathways for nitrogen removal from the sediment, sediment saturation of $\mathrm{N}$ seems unlikely.

\subsection{Implications for management}

We showed that in macrophyte-dominated CWS, both the submerged and the floating macrophytes we tested are able to remove most of the added nutrients at low $\mathrm{P}$ and $\mathrm{N}$ loadings, whereas at higher nutrient loadings, floating or submerged macrophytes could only remove $20-45$ and $10-25 \%$ of the external P loads for 21.4 and $85.7 \mathrm{mg} \mathrm{P} \mathrm{m}^{-2} \mathrm{~d}^{-1}$, respectively. For water management, regular mowing of fast 
growing aquatic macrophytes, such as A. filiculoides or $M$. spicatum allows the complete removal of added nutrients at relatively low nutrient loading ( $\leq 4.8$ or $\leq 6.8 \mathrm{mg} \mathrm{P} \mathrm{m}^{-2} \mathrm{~d}^{-1}$, respectively). Although A. filiculoides still extracted $\mathrm{P}$ and competed with sediment adsorption at higher $\mathrm{P}$ loads $\left(\geq 21.4 \mathrm{mg} \mathrm{P} \mathrm{m}^{-2} \mathrm{~d}^{-1}\right.$ ), most external $\mathrm{P}$ ended up in the sediment, eventually resulting in saturated sediments and thus leading to an increase in water nutrient levels under a continued nutrient input. While aquatic macrophytes are able to remove this $\mathrm{P}$ from the sediments by either creating anaerobic conditions to trigger high P mobilization (Smolders et al., 2006) or through both root and shoot uptake, the external load will have to be reduced for this process to occur efficiently. Consequently, at these higher $\mathrm{P}$ and $\mathrm{N}$ loads, the macrophyte stage can only be used as an additional polishing step after a major part of the nutrients have been removed by other methods of water treatment.

\section{Conclusions}

Here, we show that aquatic macrophytes can be used for polishing but not as a stand-alone purification treatment for nutrient removal from wastewater. At a low nutrient loading $M$. spicatum and A. filiculoides performed equally well for $\mathrm{P}$ removal, whereas at loads $\geq 22 \mathrm{mg} \mathrm{m}^{-2} \mathrm{~d}^{-1}$, A. filiculoides removes $P$ more efficiently. Furthermore, we have shown that sediment type is a previously underestimated factor influencing the efficiency of nutrient removal and immobilization. Especially at higher P loads, sediments form highly important sinks, and the saturation potential of the sediment is therefore important. Clay sediments should be preferred, as these take longer to become saturated than more organic sediments.

\section{Data availability}

The data associated with the paper are available from the corresponding author upon request.

\section{The Supplement related to this article is available online at doi:10.5194/bg-14-755-2017-supplement.}

Author contributions. Conception and design of the experiment: Jan G. M. Roelofs, Alfons J. P. Smolders, Leon P. M. Lamers and Monique M. L. van Kempen. Carrying out of the experiment: Evi J. H. Verbaarschot, Laury M. J. M. Loeffen and Monique M. L. van Kempen. Analysis of the data: Sarah F. Harpenslager, Yingying Tang and Evi J. H. Verbaarschot. Writing of the paper: Sarah F. Harpenslager, Yingying Tang, Alfons J. P. Smolders, Leon P. M. Lamers and Monique M. L. van Kempen
Competing interests. The authors declare that they have no conflict of interest.

Acknowledgements. The authors would like to thank Moni Poelen and Peter Cruijsen for their practical assistance and Ankie De VriesBrock, Germa Verheggen, Jelle Eygensteyn, Paul Van der Ven, Roy Peters and Sebastian Krosse for their assistance with the chemical analyses. Sarah F. Harpenslager, Monique M. L. van Kempen and Laury M. J. M. Loeffen were funded by the European Union, GO EFRO 2007-2013 (Water-Rijk, Rich Water World). Yingying Tang was funded by the China Scholarship Council (CSC; file number 201206140019).

Edited by: F. Wittmann

Reviewed by: five anonymous referees

\section{References}

Barko, J. W. and Smart, R. M.: Mobilization of sediment phosphorus by submersed freshwater macrophytes, Freshwater Biol., 10, 229-238, 1980.

Best, M. D. and Mantai, K. E.: Growth of Myriophyllum: sediment or lake water as the source of nitrogen and phosphorus, Ecology, 59, 1075-1080, 1978.

Biswas, S. and Sarkar, S.: Azolla cultivation: a supplementary cattle feed production through natural resource management, Agric. Update, 8, 670-672, 2013.

Brix, H.: Functions of macrophytes in constructed wetlands, Water Sci. Technol., 29, 71-78, 1994.

Brix, H.: How "green" are aquaculture, constructed wetlands and conventional wastewater treatment systems?, Water Sci. Technol., 40, 45-50, 1999.

Brix, H. and Arias, C. A.: The use of vertical flow constructed wetlands for on-site treatment of domestic wastewater: New Danish guidelines, Ecol. Eng., 25, 491-500, 2005.

Carignan, R. and Kalff, J.: Phosphorus sources for aquatic weeds: water or sediments?, Science, 207, 987-989, 1980.

Conley, D. J., Paerl, H. W., Howarth, R. W., Boesch, D. F., Seitzinger, S. P., Havens, K. E., Lancelot, C., and Likens, G. E.: Controlling eutrophication: nitrogen and phosphorus, Science, 323, 1014-1015, 2009.

De Lyon, M. J. H. and Roelofs, J. G. M.: Waterplanten in relatie tot waterkwaliteit en bodemgesteldheid. Deel 1 and 2, Laboratorium voor Aquatische Oecologie, Katholieke Universiteit Nijmegen, Nijmegen, 1986.

Denny, P.: Mineral cycling by wetland plants-a review, Arch. Hydrobiol. Beih. Ergebn. Limnol., 27, 1-25, 1987.

Drizo, A., Comeau, Y., Forget, C., and Chapuis, R. P.: Phosphorus saturation potential: A parameter for estimating the longevity of constructed wetland systems, Environ. Sci. Technol., 36, 46424648, 2002.

Furnas, M. M. J.: Catchments and corals: terrestrial runoff to the Great Barrier Reef, Australian Institute of Marine Science \& CRC Reef Research Centre, Townsville, Australia, 2003.

Gale, P. M., Reddy, K. R., and Graetz, D. A.: Wetlands and aquatic processes phosphorus retention by wetland soils used for treated wastewater disposal, J. Environ. Qual., 23, 370-377, 1994. 
Gao, J., Xiong, Z., Zhang, J., Zhang, W., and Mba, F. O.: Phosphorus removal from water of eutrophic Lake Donghu by five submerged macrophytes, Desalination, 242, 193-204, 2009.

Grasshoff, K. and Johannsen, H.: A new sensitive and direct method for the automatic determination of ammonia in sea water, ICES J. Mar. Sci., 34, 516-521, 1972.

Greenway, M.: The role of constructed wetlands in secondary effluent treatment and water reuse in subtropical and arid Australia, Ecol. Eng., 25, 501-509, 2005.

Handley, L. L. and Raven, J. A.: The use of natural abundance of nitrogen isotopes in plant physiology and ecology, Plant Cell Environ., 15, 965-985, 1992.

Hauck, F. W.: China: recycling of organic wastes in agriculture, Food and Agricultural Organization of the United Nations, Rome, 1978.

Henriksen, A.: An automatic method for determining low-level concentrations of phosphates in fresh and saline waters, Analyst, 90, 29-34, 1965.

Jampeetong, A., Brix, H., and Kantawanichkul, S.: Effects of inorganic nitrogen forms on growth, morphology, nitrogen uptake capacity and nutrient allocation of four tropical aquatic macrophytes (Salvinia cucullata, Ipomoea aquatica, Cyperus involucratus and Vetiveria zizanioides), Aquat. Bot., 97, 10-16, 2012.

Jing, S. R., Lin, Y. F., Lee, D. Y., and Wang, T. W.: Nutrient removal from polluted river water by using constructed wetlands, Bioresource Technol., 76, 131-135, 2001.

Kadlec, R. H. and Wallace, S. D.: Treatment wetlands, 2nd Edn., CRC press, Boca Raton, Florida, 2008.

Kamphake, L. J., Hannah, S. A., and Cohen, J. M.: Automated analysis for nitrate by hydrazine reduction, Water Res., 1, 205-216, 1967.

Kantawanichkul, S., Kladprasert, S., and Brix, H.: Treatment of high-strength wastewater in tropical vertical flow constructed wetlands planted with Typha angustifolia and Cyperus involucratus, Ecol. Eng., 35, 238-247, 2009.

Kaseva, M. E.: Performance of a sub-surface flow constructed wetland in polishing pre-treated wastewater-a tropical case study, Water Res., 38, 681-687, 2004.

Konnerup, D., Koottatep, T., and Brix, H.: Treatment of domestic wastewater in tropical, subsurface flow constructed wetlands planted with Canna and Heliconia, Ecol. Eng., 35, 248-257, 2009.

Kronvang, B., Jeppesen, E., Conley, D. J., Søndergaard, M., Larsen, S. E., Ovesen, N. B., and Carstensen, J.: Nutrient pressures and ecological responses to nutrient loading reductions in Danish streams, lakes and coastal waters, J. Hydrol., 304, 274-288, 2005.

Lamers, L. P. M., Smolders, A. J. P., and Roelofs, J. G. M.: The restoration of fens in the Netherlands, Hydrobiologia, 478, 107130, 2002.

Lin, Y. F., Jing, S. R., Wang, T. W., and Lee, D. Y.: Effects of macrophytes and external carbon sources on nitrate removal from groundwater in constructed wetlands, Environ. Pollut., 119, 413420, 2002.

Mitsch, W. J., Zhang, L., Anderson, C. J., Altor, A. E., and Hernandez, M. E.: Creating riverine wetlands: Ecological succession, nutrient retention, and pulsing effects, Ecol. Eng., 25, 510-527, 2005.
Mjelde, M. and Faafeng, B.: Ceratophyllum demersum hampers phytoplankton development in some small Norwegian lakes over a wide range of phosphorus concentrations and geographical latitude, Freshwater Biol., 37, 355-365, 1997.

Nuttall, P. M.: Uptake of phosphorus and nitrogen by Myriophyllum aquaticum (Velloza) Verd. Growing in a wastewater treatment system, Mar. Freshwater Res., 36, 493-507, 1985.

Olsen, S. R., Cole, C. V., Watanabe, F. S., and Dean, L. A.: Estimation of available phosphorus in soils by extraction with sodium bicarbonate, United States Department of Agriculture Circular No. 939, U.S. Government Printing Office, Washington, D.C., 1954.

Pretty, J. N., Mason, C. F., Nedwell, D. B., Hine, R. E., Leaf, S., and Dils, R.: Environmental costs of freshwater eutrophication in England and Wales, Environ. Sci. Technol., 37, 201-208, 2003.

R Development Core Team: R: A language and environment for statistical computing, R Foundation for Statistical Computing, Vienna, Austria, 2015.

Reddy, K. R. and DeBusk, W. F.: Growth characteristics of aquatic macrophytes cultured in nutrient-enriched water: II. Azolla, Duckweed, and Salvinia, Econ. Bot., 39, 200-208, 1985.

Reddy, K. R. and DeLaune, R. D.: Biogeochemistry of wetlands: science and applications, 1st Edn., CRC Press, Boca Raton, Florida, 2008.

RIVM (National Institute for Public Health and the Environment): Concentration and deposition maps of the Netherlands: Total Nitrogen (2014), available at: http://geodata.rivm.nl/gcn/, last access: 21 December 2016.

Scholz, M. and Xu, J.: Performance comparison of experimental constructed wetlands with different filter media and macrophytes treating industrial wastewater contaminated with lead and copper, Bioresource Technol., 83, 71-79, 2002.

Smith, C. S. and Adams, M. S.: Phosphorus transfer from sediments by Myriophyllum spicaturn, Limnol. Oceanogr., 31, 1312-1321, 1986.

Smolders, A. J. P., Lamers, L. P. M., Lucassen, E. C. H. E. T., Van Der Velde, G., and Roelofs, J. G. M.: Internal eutrophication: How it works and what to do about it-a review, Chem. Ecol., 22, 93-111, 2006.

Tanner, C. C.: Plants for constructed wetland treatment systems-A comparison of the growth and nutrient uptake of eight emergent species, Ecol. Eng., 7, 59-83, 1996.

Tomassen, H. B. M., Smolders, A. J. P., Limpens, J., Lamers, L. P. M., and Roelofs, J. G. M.: Expansion of invasive species on ombrotrophic bogs: desiccation or high $\mathrm{N}$ deposition?, J. Appl. Ecol., 41, 139-150, 2004.

Van Dongen, U., Jetten, M. S. M., and Van Loosdrecht, M. C. M.: The SHARON ${ }^{\circledR}$-Anammox ${ }^{\circledR}$ process for treatment of ammonium rich wastewater, Water Sci. Technol., 44, 153-160, 2001.

Van Kempen, M. M. L.: Azolla on top of the world: an ecophysiological study of floating fairy moss and its potential role in ecosystem services related to climate change, $\mathrm{PhD}$ thesis, Aquatic Ecology \& Environmental Biology, Radboud University Nijmegen, the Netherlands, 165 pp., 2013.

Van Kempen, M. M. L., Smolders, A. J. P., Lamers, L. P. M., and Roelofs, J. G. M.: Micro-halocline enabled nutrient recycling may explain extreme Azolla event in the Eocene Arctic Ocean, PLoS ONE, 7, e50159, doi:10.1371/journal.pone.0050159, 2012. 
Van Loosdrecht, M. C. M. and Jetten, M. S. M.: Microbiological conversions in nitrogen removal, Water Sci. Technol., 38, 1-7, 1998.

Vrhovšek, D., Kukanja, V., and Bulc, T.: Constructed wetland (CW) for industrial waste water treatment, Water Res., 30, 2287-2292, 1996.

Vymazal, J.: Removal of nutrients in various types of constructed wetlands, Sci. Total Environ., 380, 48-65, 2007.

Vymazal, J.: Plants used in constructed wetlands with horizontal subsurface flow: a review, Hydrobiologia, 674, 133-156, 2011.
Wetzel, R. G.: Limnology: lake and river ecosystems, 3rd Edn., Academic Press, San Diego, California, 2001.

Wittgren, H. B. and Mæhlum, T.: Wastewater treatment wetlands in cold climates, Water Sci. Technol., 35, 45-53, 1997.

Wu, S., Kuschk, P., Brix, H., Vymazal, J., and Dong, R.: Development of constructed wetlands in performance intensifications for wastewater treatment: A nitrogen and organic matter targeted review, Water Res., 57, 40-55, 2014. 